\title{
Determination of optimum insulation and cement plaster thickness for bungalow buildings through a simulation-statistical approach using response surface methodology
}

\author{
Iman Asadi ${ }^{1,2^{*}}$, Payam Shafigh ${ }^{1,2}$, Norhayati Binti Mahyuddin ${ }^{1,2^{*}}$, Hossein Akbari ${ }^{3}$ \\ ${ }^{1}$ Department of Building Surveying, Faculty of Built Environment, University of Malaya, 50603 \\ Kuala Lumpur, Malaysia \\ ${ }^{2}$ Centre for Building, Construction \& Tropical Architecture (BuCTA), Faculty of Built \\ Environment, University of Malaya, Kuala Lumpur, Malaysia \\ ${ }^{3}$ Trauma Research Center, Kashan University of Medical Sciences, Qutb-e Ravandi Blvd. \\ Postcode: 8715988141, Kashan, IR Iran.
}

asadi8564@gmail.com; hayati@um.edu.my

Received: 18 June 2018 Final Version Received: 28 August 2019

\begin{abstract}
Insulating interior side of external wall and finishing by cement plaster is one of the most appropriate methods of reducing annual energy consumption in available buildings. The aim of this study is to determine the optimum expanded polystyrene (EPS) and cement plaster thickness for bungalow building in Malaysia. The present study evaluates the effect of different thermal insulation and interior cement plaster thicknesses on the annual cooling energy consumption. Furthermore, the optimum thickness of EPS and plaster is estimated based on wall type and building orientation. Two different types of walls made of concrete and brick are considered. EPS and plaster were used in the range of 20 to $100 \mathrm{~mm}$ and 0 to $20 \mathrm{~mm}$, respectively. The results show that both thermal insulation and plaster thickness have a direct effect on annual cooling energy consumption, however, the influence of wall thermal insulation thickness is more significant than cement plaster thickness. Further, the optimum EPS thickness decreases with the increment in cement plaster thickness for different orientations and wall types. The optimum EPS thickness ranges from $31.5 \mathrm{~mm}$ to $53.1 \mathrm{~mm}$ based on wall type, orientation and cement plaster thickness. Utilizing optimum EPS and cement plaster thicknesses can thus reduce annual energy consumption by about 6 to $12 \%$ in different directions.
\end{abstract}

Keywords: Thermal Insulation, Cement Plaster, Energy Consumption, Simulation, Response Surface Methodology (RSM)

\section{INTRODUCTION}

Total end-user energy consumption is linked to the transportation, industrial, residential, commercial and other sectors with contributions of $30 \%, 29 \%, 27 \%, 9 \%$ and $5 \%$, respectively (Parameshwaran et al., 2012). One-third of the total energy consumption and $30 \%$ of greenhouse gas emissions are attributed to buildings in most countries (Martínez-Molina et al., 2016; D. Zhang et al., 2004). Finding new means of saving energy in the building sector is essential due to the limited natural energy sources and rise in population (Shafigh et al., 2018) . Fabric and ventilation heat transfer are two reasons for heat loss in buildings. Fabric heat loss is related to conduction heat transfer through walls, roofs, windows and floors.
Ventilation heat loss is a type of convective heat transfer whereby air is replaced by heating, ventilation, and air conditioning systems.

In Malaysia, residential buildings consume about $19 \%$ of the total energy (Saidur et al., 2007). The average building energy index (BEI) in south-east Asia is about $233 \mathrm{KWh} / \mathrm{m}^{2} /$ year, whereas the Malaysian average is 269 $\mathrm{kWh} / \mathrm{m}^{2} /$ year. Around $45 \%$ up to $70 \%$ of the energy consumed by Malaysian buildings is attributed to cooling equipment (Hassan \& AlAshwal, 2015; Rahman et al., 2008). However, cooling energy consumption may be reduced by limiting the amount of heat transfer through the building envelope (Mirrahimi et al., 2016). Using materials with high heat resistance in the building envelope is a suitable method of 
reducing the annual cooling load and peak cooling demand for buildings in hot and humid regions. Hassan and Al-Ashwal (Hassan \& AlAshwal, 2015) reported that exterior wall thermal insulation facilitates significant reductions in annual cooling energy by up to $20 \%$ in Malaysian buildings. However, Iqbal et al. (Iqbal \& Al-Homoud, 2007) reported only 2\% energy savings by increasing the insulation thickness from 50 to $75 \mathrm{~mm}$.

Thick insulation reduces energy consumption, although it increases construction costs and reduces internal spaces. Hence, it is vital to identify the optimum thickness for thermal insulation. Expanded polystyrene (EPS), extruded polystyrene (XPS), polyurethane (PUR), mineral wool (MW), foam glass (FG) and glass wool (GW) are commonly used insulation materials in the construction industry (Braulio-Gonzalo \& Bovea, 2017). Various studies have evaluated the optimum thickness of insulation materials. Axaopoulos et al. (Axaopoulos et al., 2015) evaluated the most economic optimum insulation thicknesses of numerous insulation materials utilized in the external walls of buildings in Cyprus with different orientations and wall topologies. They reported optimum insulation thicknesses for various wall topologies and orientations from 42.5 to $155 \mathrm{~mm}$. Al-Sanea et al. (Al-Sanea et al., 2016) considered economic, optimum insulation thicknesses for a range of wall topologies comprising different thermal insulation materials in a number of cities in Saudi Arabia. They revealed that the optimum thickness varies from $20 \mathrm{~mm}$ to $84 \mathrm{~mm}$ depending on the climate and type of insulation.

Mahlia and Iqbal (Mahlia \& Iqbal, 2010) revealed that the optimum insulation thickness is between 15 to $60 \mathrm{~mm}$ depending on the air gap thickness and insulation material. Dombayc1 (Dombayc1, 2007) reported that the optimum insulation thickness is about $95 \mathrm{~mm}$ in buildings in Turkey. However, another study indicated that the optimum insulation thickness in Turkey ranges from 10 to $70 \mathrm{~mm}$ depending on fuel type and weather conditions (Ucar \& Balo, 2009). Yu et al. (Yu et al., 2009) reported optimum thicknesses of different insulation types in the range of 50 to $230 \mathrm{~mm}$. Ashouri et al. (Ashouri et al., 2016) found that the optimum thickness varies from 94 to $220 \mathrm{~mm}$ based on wall thickness and insulation type.

Mahlia et al. (Mahlia et al., 2007) reported that the optimum insulation material thickness is around 40 to $100 \mathrm{~mm}$. In addition, they proposed the following correlation between thermal conductivity and thermal insulation material thickness:

$$
\mathrm{x}_{\mathrm{opt}}=\mathrm{a}+\mathrm{bk}+\mathrm{ck}^{2}
$$

Where $\mathrm{x}$ is the insulation thickness $(\mathrm{m}), \mathrm{k}$ is the thermal conductivity of the insulation $(\mathrm{W} / \mathrm{mK})$, $\mathrm{a}=0.0818, \mathrm{~b}=-2.973$ and $\mathrm{c}=64.6$.

EPS is a white foam plastic insulation material, which is manufactured by expanding polystyrene. The cost of EPS varies from 6.54 $€ /$ unit to $47.97 € /$ unit, while the commercial thickness ranges from 30 to $220 \mathrm{~mm}$. The thermal conductivity, density and specific heat capacity of EPS are in the ranges of 0.029-0.037 w/m.k, $15-75 \mathrm{~kg} / \mathrm{m}^{3}$ and $1-1.25 \mathrm{kj} / \mathrm{kg} . \mathrm{k}$, respectively (Schiavoni et al., 2016) . BraulioGonzalo and Bovea (Braulio-Gonzalo \& Bovea, 2017) reported that the optimum EPS thicknesses are $110 \mathrm{~mm}, 90 \mathrm{~mm}$ and $50 \mathrm{~mm}$ when used as roof, façade and floor insulators, respectively. Ozel (Ozel, 2011) revealed that the optimum EPS thicknesses are $74 \mathrm{~mm}$ and $82 \mathrm{~mm}$ for concrete and brick structures, respectively. According to Derradji et al. (Derradji et al., 2017), the optimum EPS thickness is between 10 and $25 \mathrm{~mm}$.

Cement mortar (surface mortar) is plastered on building surfaces to prepare durable, smooth surfaces. Numerous studies have referred to diverse types of plaster used as wall finishing. Most researchers have focused on insulation thickness variations and assumed a constant thickness for plaster. Simona et al. (Simona et al., 2017) employed 8 and 20mm plaster for different parts of a wall. Ozel (Ozel, 2011) and Ji et al. (Ji et al., 2017) considered 20mm thick plaster for walls. Ashouri et al. (Ashouri et al., 2016) considered the optimum insulation thickness for a brick wall containing $10 \mathrm{~mm}$ and $20 \mathrm{~mm}$ plaster inside and outside, respectively. Roberz et al. (Roberz et al., 2017) and Naji et al. (Naji et al., 2014) selected $10 \mathrm{~mm}$ plaster as wall finishing.

Based on the available literature, the optimum thickness of insulation materials varies according to wall thickness, wall topology, building orientation, weather conditions, insulation type and wall type. It appears from the literature that no study has evaluated the effects of cement plaster thickness on the optimum wall insulation thickness and building energy consumption. In the most available studies the thickness of cement mortar considered constant and the effect of this layer of wall on total heat transfer through walls has not been considered. Hence, the aim of this study is to evaluate the 
effect of both thermal insulation thickness and cement plaster thickness on the annual energy consumption of an air-conditioned bungalow. Another objective of this research is to determine the optimum EPS thickness for Malaysian buildings based on wall type, orientation, and cement plaster applied within. The results indicate potential energy savings for bungalows with different orientations.

To fulfil the objectives, the annual energy consumption of a tropical single-story bungalow is simulated while the walls containing EPS and cement mortar in different thicknesses. Then, the achieved data of simulation are inserted to the design expert software to find the optimum thickness of EPS and cement mortar through RSM. Finally, the amount of energy consumption reduction of building in present of optimum thickness of EPS and plaster is calculated.

\section{MATERIALS AND METHOD}

\subsection{Climate conditions and comfort temperature}

The geographic location of Kuala Lumpur as the capital of Malaysia is at latitude $3.13 \mathrm{~N}$ and longitude 101.68'E (Fig. 1). Malaysia's tropical climate is hot and humid. The insolation (solar radiation energy shining on a horizontal surface) in Malaysia is depicted in Fig. 3. Data obtained for a ten-year period shows that outdoor temperatures are relatively uniform with average temperatures between $23.7 \mathrm{C}$ and $31.3^{\circ} \mathrm{C}$ throughout a day with the highest maximum recorded of $36.9^{\circ} \mathrm{C}$. The average relative humidity throughout a day is between $67 \%$ and $95 \%$ (Asadi et al., 2014b). Regarding the Malaysia climate, cooling systems are considered among the principal energy consumption aspects in the building sector.

Based on the Department of Standards Malaysia, indoor temperatures should be in the range of $23^{\circ} \mathrm{C}$ to $26^{\circ} \mathrm{C}$ in an air-conditioned room (Jamaludin et al., 2015). Ahmad and Szokolay (Ahmad \& Szokolay, 2007) revealed that the comfort temperature is between $23.6 \mathrm{C}$ and $28.6 \mathrm{C}$ in air-conditioned apartment buildings in Malaysia. Asadi et al. (Asadi et al., 2014a) reported that the comfort range is between $23.1^{\circ} \mathrm{C}$ and $24.7^{\circ} \mathrm{C}$ and the acceptable range is $22.6^{\circ} \mathrm{C}$ to $25.3^{\circ} \mathrm{C}$ for air-conditioned university classrooms. Mahila et al. (Mahlia et al., 2007) selected $21^{\circ} \mathrm{C}$ as the indoor comfort temperature to calculate the optimum insulation material thickness in commercial Malaysian buildings; however, other studies reported 23.9 $9^{\circ} \mathrm{C}$ (Asadi et al., 2014a) and 22.5C (Yau et al., 2013) as the neutral air temperature at UNITEN university and the National Museum of Malaysia, respectively .

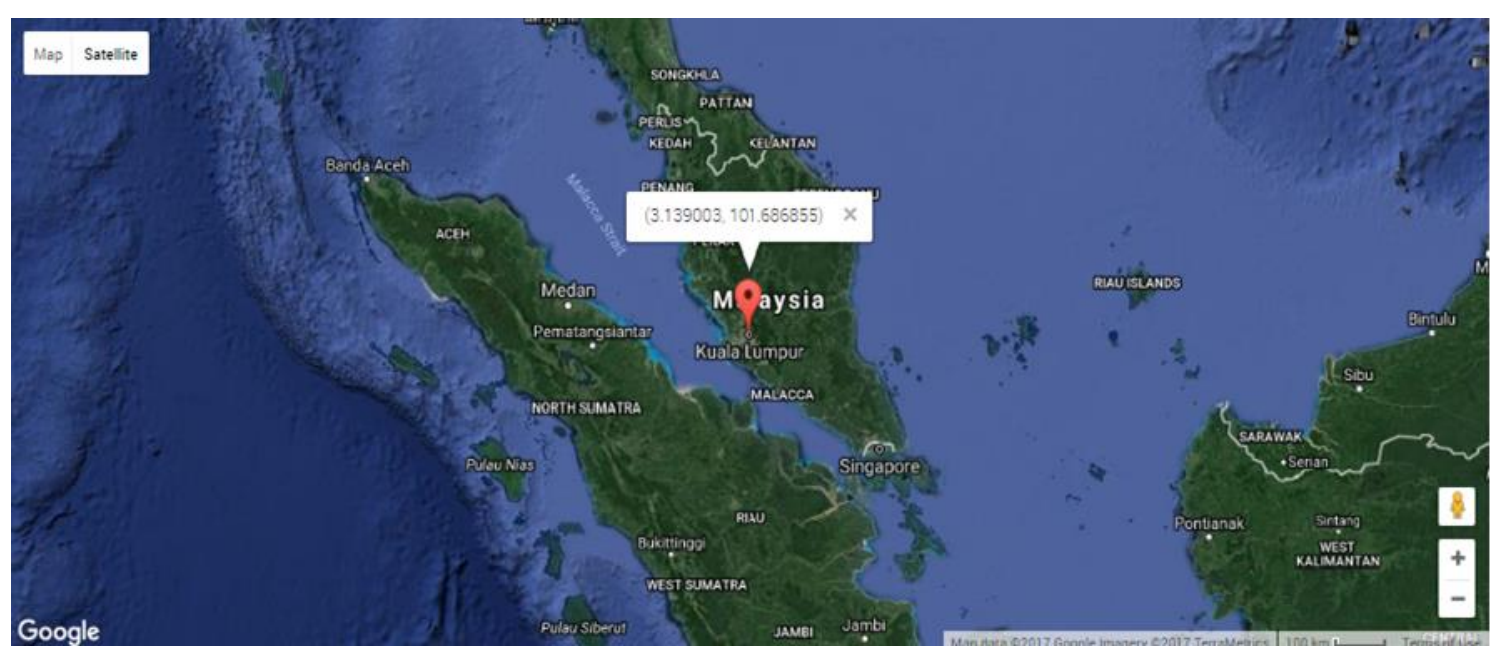

Figure 1 - Geographic location of Kuala Lumpur. 


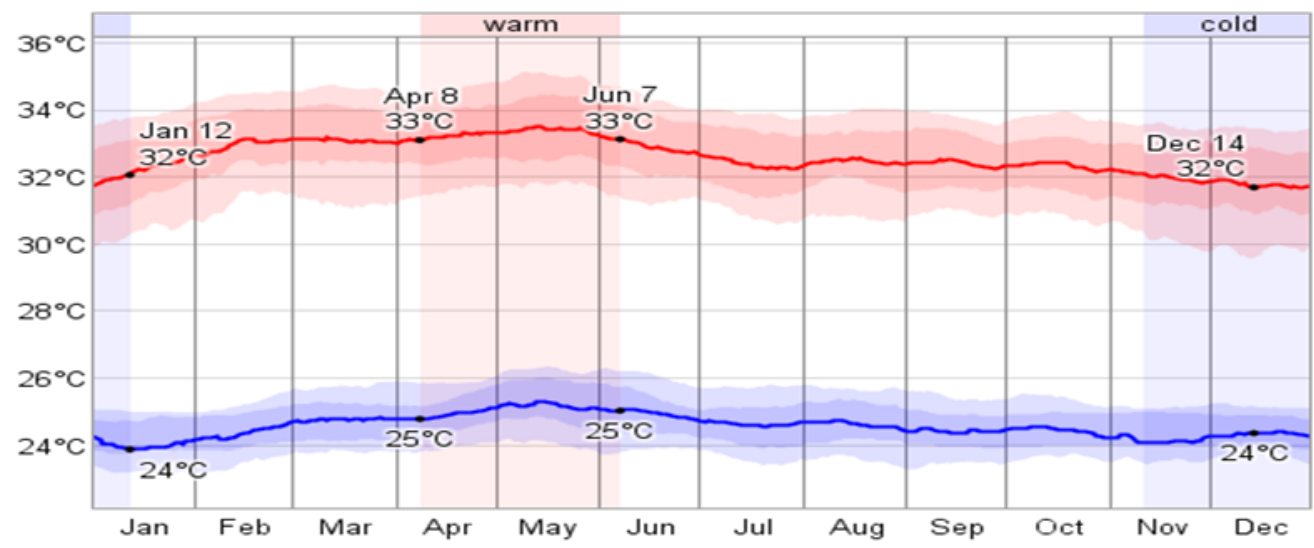

Figure 2- Daily average low and high temperatures with percentile bands (Mirrahimi et al., 2016).

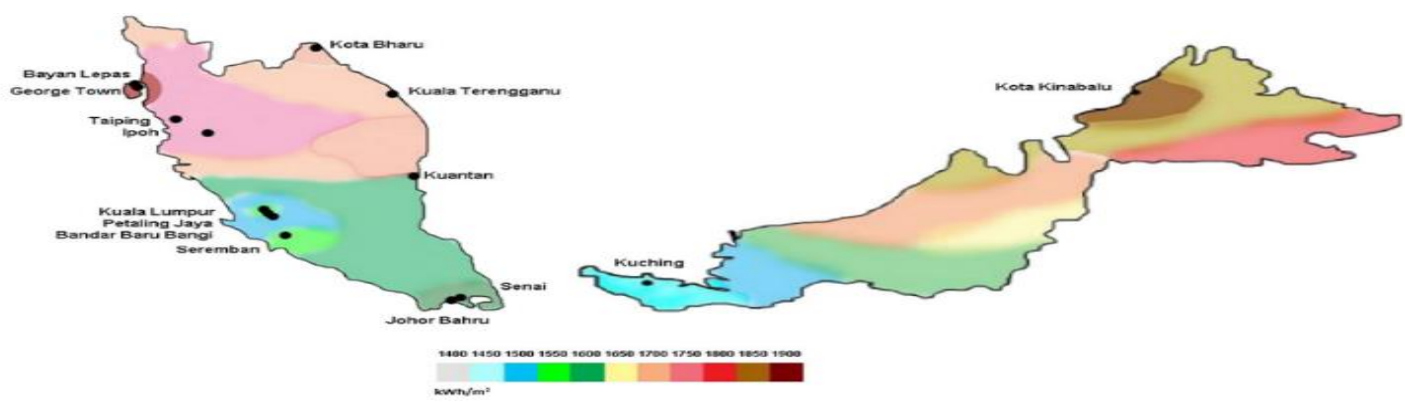

Figure 3- Malaysian map of yearly insolation (Muhammad-Sukki et al., 2011).

\subsection{Heat transfer and wall configuration}

\subsubsection{Governing heat transfer equations}

Heat transfer is a vector quantity that occurs through conduction, convection and radiation (Incropera \& DeWitt, 1985). Conduction heat transfer in solids is a mixture of molecule vibrations and energy transport by free electrons (Bhattacharjee \& Krishnamoorthy, 2004). The energy consumption in buildings is extremely dependent on the thermal conductivity values of the building materials. Thermal conductivity is a property of a material, which demonstrates its heat conduction capability (Asadi et al., 2018; W. Zhang et al., 2015). In convection, heat flows through the movement of liquid or gas molecules (between solids and fluids). In radiation, heat flows through electromagnetic waves.

The rate of total heat lost or gained by a building surface through conduction, convection and radiation can be calculated using Eq. 2 .

$\mathrm{q}(\mathrm{t})=\sum_{i} A_{i} U_{i}\left[T_{i}-T_{o}(t)\right]$

Where $A_{i}$ is the building component surface area, $\mathrm{Ui}$ is the $\mathrm{U}$ value of each building component, $T_{i}$ is the indoor temperature and $T_{o}$ is the temperature of the ground and the outside air.

The U value of a wall is calculated by:

$$
U=\frac{1}{R_{t}}
$$

Where $R_{t}$ is the wall's total heat resistance given by:

$$
R_{t}=\frac{1}{h_{i}}+\left(\sum_{i=1}^{n} \frac{l_{i}}{k_{i}}\right)+\frac{1}{h_{o}}
$$

Where $h_{i}$ and $h_{o}$ are the inside and outside heat transfer coefficients, $\mathrm{L}$ is the layer thickness and $\mathrm{k}$ is the thermal conductivity of the related material.

\subsubsection{Wall configuration}

Two different walls were designed for use as exterior walls in a bungalow building. The first consists of $200 \mathrm{~mm}$ concrete and the second is made of $200 \mathrm{~mm}$ brick. Both walls' exterior surfaces were covered with $10 \mathrm{~mm}$ of cement plaster. The interior surfaces contained expanded polystyrene (EPS) as the thermal 
insulation material and cement plaster coating ranging from $20 \mathrm{~mm}$ to $100 \mathrm{~mm}$ and $0 \mathrm{~mm}$ to 20 , respectively (Fig. 4). The length and thermal properties of the designed walls are summarized in Table 1.

Table 1- Size and thermo-physical properties of the materials employed.

\begin{tabular}{|c|c|c|c|c|}
\hline Wall layer & $\begin{array}{c}\text { Thickness } \\
(\mathrm{mm})\end{array}$ & $\begin{array}{c}\text { Thermal conductivity } \\
(\mathrm{W} / \mathrm{m} K)\end{array}$ & $\begin{array}{c}\text { Heat capacity } \\
(\mathrm{KJ} / \mathrm{KgK})\end{array}$ & $\begin{array}{c}\text { Density } \\
\left(\mathrm{Kg} / \mathrm{m}^{3}\right)\end{array}$ \\
\hline Cement plaster & 10 & 0.72 & 0.84 & 1860 \\
\hline Concrete & 200 & 2.3 & 0.83 & 2500 \\
\hline Brick & 200 & 0.45 & 1 & 1200 \\
\hline EPS & $20-100$ & 0.03 & 1.5 & 20 \\
\hline Cement plaster & $0-20$ & 0.72 & 0.84 & 1860 \\
\hline
\end{tabular}

Figure 4 Wall topology

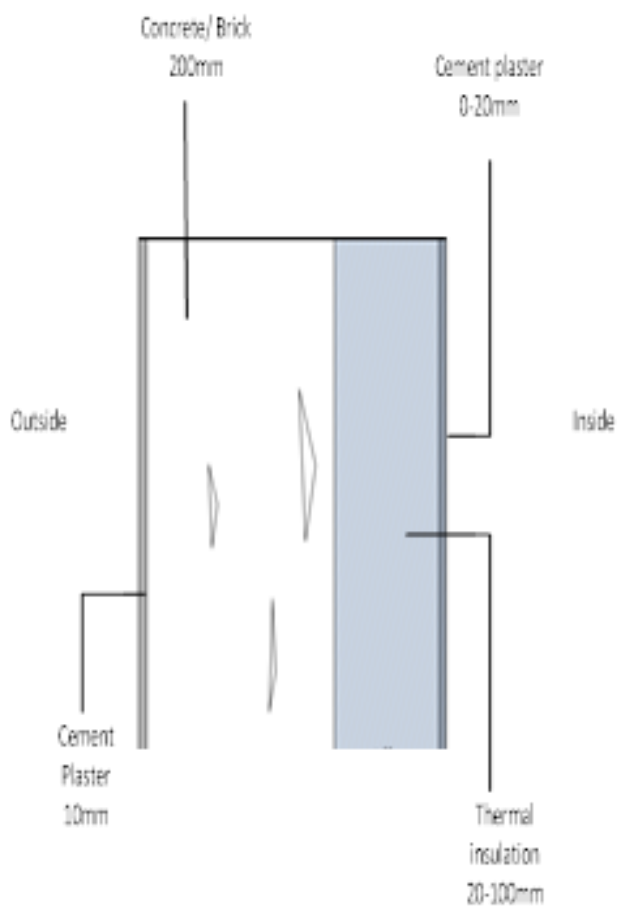

The total thermal resistance of a wall is calculated as follows:

$$
R_{t}=\frac{1}{h_{o}}+\frac{L_{C O}}{K_{C o}}+\frac{L_{w}}{K_{w}}+\frac{L_{t h}}{K_{t h}}+\frac{L_{C i}}{K_{C i}}+\frac{1}{h_{i}}
$$

The $\mathrm{L}$ and $\mathrm{K}$ values for the different layers are available in Table 1. The convective heat transfer coefficients for internal and external building surfaces are functions of building geometry, local airflow patterns, building facade roughness, building surroundings and temperature differences. Different equations for calculating the convective heat transfer coefficient of walls based on air velocity are presented in (Emmel et al., 2007).

\subsection{Statistical analysis and optimization}

Factorial design analysis and response surface methodology (RSM) are deemed suitable tools to determine the optimal conditions (Gheshlaghi et al., 2008). RSM was originally presented for modeling in experimental studies and was subsequently utilized to address numerical simulation modeling. RSM prospect the relation between the variables and one or more response. 
RSM includes statistical and mathematical techniques based on the fit of obtained data to the polynomial equation.

In experimental tests, inaccuracies during measurements can be the result of errors. Though in computer simulation, round-off errors, inadequate convergence of iterative processes, or the discrete representations of continuous physical phenomena are sources of numerical noise (Tabatabaeikia et al., 2016).

Design-Expert software version 7.0.0 was used to design a simulation model as well as to analyze and optimize the statistical results. The impact of four factors, including indoor cement plaster thickness, heat insulation thickness, wall type, and building orientation on the annual cooling energy consumption was examined using analysis of variance (ANOVA).

The simulation design employed in this study is the Central Composite Design (CCD) with three levels $(+1,0,-1)$ for two numeric factors including cement plaster and thermal insulation thicknesses. In addition, the model consists of wall type and building orientation as the categorical variables.

\subsection{Cooling energy consumption simulation}

\subsubsection{Sample building}

A typical sample of a tropical single-story bungalow constructed in Malaysia is shown in Fig. 5. The footprint area of the building is about $180 \mathrm{~m}^{2}$. It consists of three bedrooms (one master room + two normal rooms), one small room, kitchen, restrooms, a dining room and a living room.

Figure 5- Indoor space layout

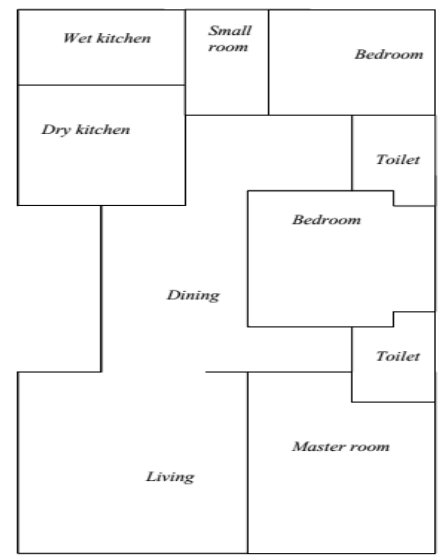

\subsubsection{Energy modeling in eQUEST}

Recently, several building performance simulation software with different simulation engines have been utilized to analyze the energy consumption of buildings. Building energy simulation is an adequate technique to evaluate diverse construction material choices and architectural design decisions and to analyze the energy performance of buildings (Asadi et al., 2017). Data exchange reliability and userfriendly interface are the main features of a practical simulation software.

eQUEST is a helpful graphical user interface for the DOE-2 engine. DOE-2, as one of the greatest general programs for building simulation. This software is capable of modeling building energy consumption in reasonable of short time in case of large buildings. In the present study, eQUEST 3.65 was applied. First, the schematic design wizard (SD) was selected to simulate the building envelope. A summary of the input data is available in Table 2. The building envelope designed was transferred to the design development wizard (DD) to define different HVAC systems and assign related thermal zones.

To simplify the model, two thermal zones were designed. One zone consists of the living, dining and master rooms as the air-conditioned zone and the second zone entails the rest of the house as mechanically ventilated areas. Based on the literature, most air-conditioned houses in Malaysia utilize cooling systems in the master bedroom and living area, especially during the night. A daily average of 6 hours of air conditioning have been reported (Sabouri \& Zain, 2011). In this study, a split system with DX cooling and a direct return air path was designed for the air-conditioned zone. The cooling thermostat was designed with $24^{\circ} \mathrm{C}$ while the fan (on) mode is intermittent. The simulated building is occupied from $6 \mathrm{pm}$ to 9 am on weekdays and the entire day on weekends. A summary of HVAC systems is presented in Table 3. The building and HVAC system simulated by eQUEST for energy consumption analysis are shown in Fig. 6. Finally, detailed eQUEST data were employed to simulate annual cooling energy consumption. eQUEST was run 72 times for different $U$ values of the external walls and different orientations according to design expert suggestions.

Table 2 - Summary of input data in eQUEST 


\begin{tabular}{|l|l|}
\hline Input parameters & $\begin{array}{l}\text { Simulation } \\
\text { specifications }\end{array}$ \\
\hline Building type & Multifamily, low-rise \\
\hline Shell area & $180 \mathrm{~m}^{2}$ \\
\hline Number of floors & 1 \\
\hline Weather file & K-LUMPUR.BIN \\
\hline Type of roof & Pitched roof \\
\hline Roof construction & $\begin{array}{l}\text { Layer-by-layer(clay tile- } \\
\text { concrete slab-cement } \\
\text { mortar-finish) }\end{array}$ \\
\hline Heat transfer of wall & Overall U-value \\
\hline Door/window type & $\begin{array}{l}\text { Opaque/Double } \\
\text { reflective }\end{array}$ \\
\hline $\begin{array}{l}\text { Overall time of air } \\
\text { conditioner usage }\end{array}$ & $6 \mathrm{~h}$ \\
\hline $\begin{array}{l}\text { Overall time of } \\
\text { ventilation usage }\end{array}$ & $24 \mathrm{~h}$ \\
\hline
\end{tabular}

Table 3- Summary of HVAC systems

\begin{tabular}{|c|c|c|}
\hline \multirow[b]{2}{*}{ Parameters } & \multicolumn{2}{|c|}{ Types of HVAC } \\
\hline & $\begin{array}{c}\text { Split } \\
\text { Direct } \\
\text { expansion } \\
\text { (DX) }\end{array}$ & Ventilator \\
\hline Cooling source & DX coil & ------------------ \\
\hline Heating source & ----------------- & |----------------- \\
\hline Return area path & Direct & ----------------- \\
\hline $\begin{array}{l}\text { Cooling design } \\
\text { temperature }\end{array}$ & $24^{\circ} \mathrm{C}$ & -- \\
\hline $\begin{array}{c}\text { Cooling supply } \\
\text { temperature }\end{array}$ & $13^{\circ} \mathrm{C}$ & -- \\
\hline $\begin{array}{l}\text { Minimum design } \\
\text { flow }\end{array}$ & $2.54 \mathrm{l} / \mathrm{s} . \mathrm{m}^{2}$ & $2.541 / \mathrm{s} . \mathrm{m}^{2}$ \\
\hline EER & 8.5 & ----------------- \\
\hline
\end{tabular}

Figure 6- Simulated building and HVAC system: (a) 2-D geometry, (b) 3-D geometry, (c) cooling system and (d) ventilation system.

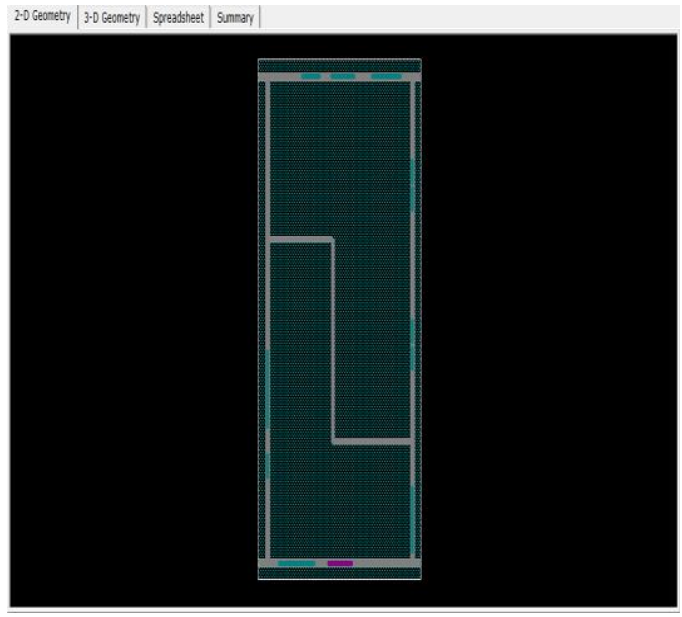

(a)

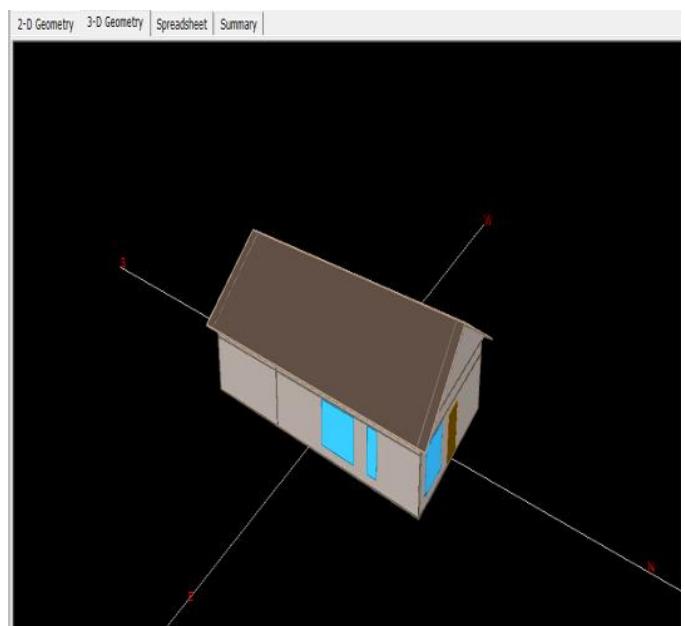

(b)

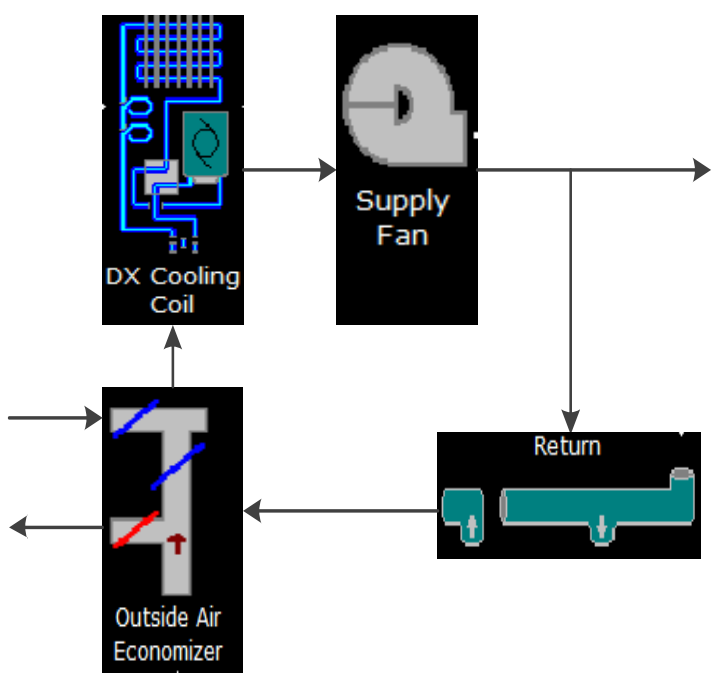

(c)

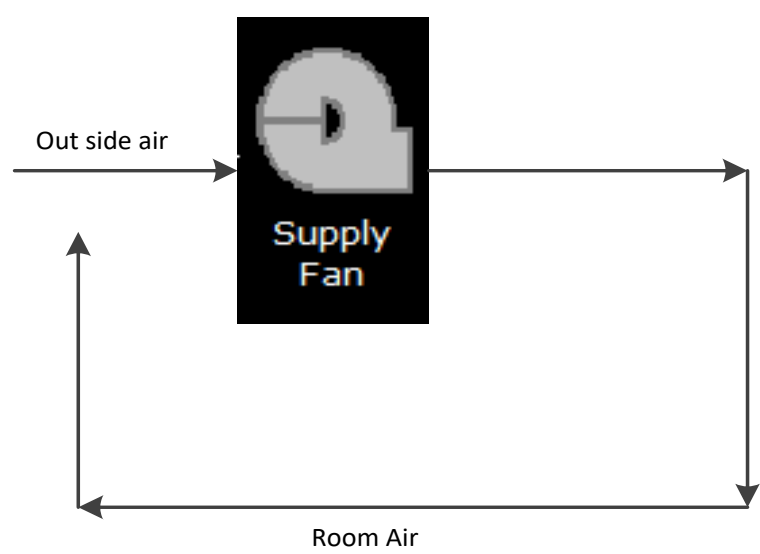

(d) 


\section{RESULTS AND DISCUSSION}

\subsection{Statistical results}

The results obtained from eQUEST were inserted into the Design-Expert software to carry out the statistical analysis and optimization based on RSM. Analysis of variance (ANOVA), a reliable way to analyze fitted model quality, makes a comparison between the deviation caused by the treatment and variation caused by random errors. The design summary is given in Table 4.

Table 4 - Input and output summary of Design-Expert

\begin{tabular}{|c|c|c|c|c|c|c|c|c|c|}
\hline Factor & Name & Units & Type & $\begin{array}{c}\text { Low } \\
\text { Actual }\end{array}$ & $\begin{array}{l}\text { High } \\
\text { Actual }\end{array}$ & $\begin{array}{c}\text { Low } \\
\text { Coded }\end{array}$ & $\begin{array}{c}\text { High } \\
\text { Coded }\end{array}$ & Mean & $\begin{array}{l}\text { Std. } \\
\text { Dev. }\end{array}$ \\
\hline A & $\begin{array}{l}\text { Cement } \\
\text { plaster } \\
\text { thickness }\end{array}$ & $\mathrm{mm}$ & Numeric & 0 & 20 & -1 & 1 & 10 & 8.165 \\
\hline B & $\begin{array}{l}\text { Thermal } \\
\text { insulation } \\
\text { thickness }\end{array}$ & $\mathrm{mm}$ & Numeric & 20 & 100 & -1 & 1 & 60 & 32.660 \\
\hline $\mathrm{C}$ & Type of wall & ---- & Categoric & Concrete & Brick & ---- & ---- & \multicolumn{2}{|c|}{ Levels: 2} \\
\hline D & Orientation & ---- & Categoric & North & South & ---- & ---- & \multicolumn{2}{|c|}{ Levels: 4} \\
\hline Response & Name & Units & Obs & Analysis & Min & Max & Mean & $\begin{array}{l}\text { Std. } \\
\text { Dev. }\end{array}$ & Ratio \\
\hline Y1 & $\begin{array}{c}\text { Annual } \\
\text { cooling } \\
\text { energy } \\
\text { consumption }\end{array}$ & KWh & 72 & Polynomial & 2018.9 & 2324 & 2113.88 & 88.22 & 1.15 \\
\hline
\end{tabular}

Design-Expert software suggested a quadratic model to generate the response surface. This suggestion is based on the amount of adjusted $R^{2}$ (0.989) and predicted $\mathrm{R}^{2}(0.986)$, which are close to 1 (Table 5). The mathematical models between the response (annual cooling energy consumption) and independent variables (type of wall, orientation, cement plaster thickness, and thermal insulation thickness) are represented in Table 6 .

Table 5 - Model comparison based on R-square

\begin{tabular}{|c|c|c|c|c|c|c|}
\hline Source & Dev. & R-Squared & $\begin{array}{c}\text { Adjusted } \\
\text { R-Squared }\end{array}$ & $\begin{array}{l}\text { Predicted } \\
\text { R-Squared }\end{array}$ & PRESS & \\
\hline Linear & 33.1918 & 0.8722 & 0.8604 & 0.8440 & 87390.09 & \\
\hline $2 \mathrm{FI}$ & 30.2020 & 0.9137 & 0.8844 & 0.8529 & 82390.25 & \\
\hline Quadratic & 9.0800 & 0.9924 & 0.9895 & 0.9861 & 7767.42 & Suggested \\
\hline Cubic & 4.9247 & 0.9986 & 0.9969 & 0.9927 & 4057.03 & Aliased \\
\hline
\end{tabular}

Table 6 - Correlation between annual cooling energy consumption and cement plaster thickness, and thermal insulation thickness for different walls with different orientations

\begin{tabular}{|c|c|c|}
\hline \multirow{2}{*}{$\begin{array}{c}\text { Type } \\
\text { of wall }\end{array}$} & Orientation & Annual cooling energy consumption equation \\
\hline \multirow{4}{*}{ Concrete } & North & $2392.815-(0.638 \mathrm{~A})-(6.845 \mathrm{~B})+(0.003 \mathrm{AB})+\left(0.008 \mathrm{~A}^{2}\right)+\left(0.032 \mathrm{~B}^{2}\right)$ \\
\cline { 2 - 3 } & West & $2377.979-(0.591 \mathrm{~A})-(6.804 \mathrm{~B})+(0.003 \mathrm{AB})+\left(0.008 \mathrm{~A}^{2}\right)+\left(0.032 \mathrm{~B}^{2}\right)$ \\
\cline { 2 - 3 } & East & $2330.645-(0.626 \mathrm{~A})-(6.353 \mathrm{~B})+(0.003 \mathrm{AB})+\left(0.008 \mathrm{~A}^{2}\right)+\left(0.032 \mathrm{~B}^{2}\right)$ \\
\cline { 2 - 3 } & South & $2454.417-(0.951 \mathrm{~A})-(7.113 \mathrm{~B})+(0.003 \mathrm{AB})+\left(0.008 \mathrm{~A}^{2}\right)+\left(0.032 \mathrm{~B}^{2}\right)$ \\
\hline
\end{tabular}




\begin{tabular}{|c|l|l|}
\hline \multirow{4}{*}{ Brick } & North & $2298.671-(0.405 \mathrm{~A})-(5.903 \mathrm{~B})+(0.003 \mathrm{AB})+\left(0.008 \mathrm{~A}^{2}\right)+\left(0.032 \mathrm{~B}^{2}\right)$ \\
\cline { 2 - 3 } & West & $2285.590-(0.358 \mathrm{~A})-(5.863 \mathrm{~B})+(0.003 \mathrm{AB})+\left(0.008 \mathrm{~A}^{2}\right)+\left(0.032 \mathrm{~B}^{2}\right)$ \\
\cline { 2 - 3 } & East & $2239.476-(0.393 \mathrm{~A})-(5.412 \mathrm{~B})+(0.003 \mathrm{AB})+\left(0.008 \mathrm{~A}^{2}\right)+\left(0.032 \mathrm{~B}^{2}\right)$ \\
\cline { 2 - 3 } & South & $2352.872-(0.718 \mathrm{~A})-(6.172 \mathrm{~B})+(0.003 \mathrm{AB})+\left(0.008 \mathrm{~A}^{2}\right)+\left(0.032 \mathrm{~B}^{2}\right)$ \\
\hline
\end{tabular}

Fig. 7 and Fig. 8 represent the interaction effects of cement plaster thickness and thermal insulation thickness for different orientations and walls on annual cooling energy consumption. The 3D surface graphs indicate that the influence of thermal insulation thickness is more significant than cement plaster thickness on the amount of annual cooling energy consumption.

Figure 7 - Concrete wall building: Interactions of cement plaster thickness and thermal insulation thickness with annual cooling energy consumption (KWh) for different orientations.

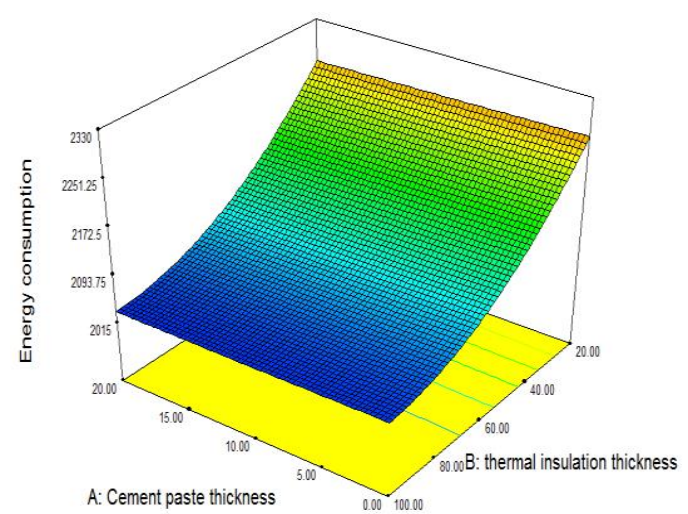

(a)North



(b) West

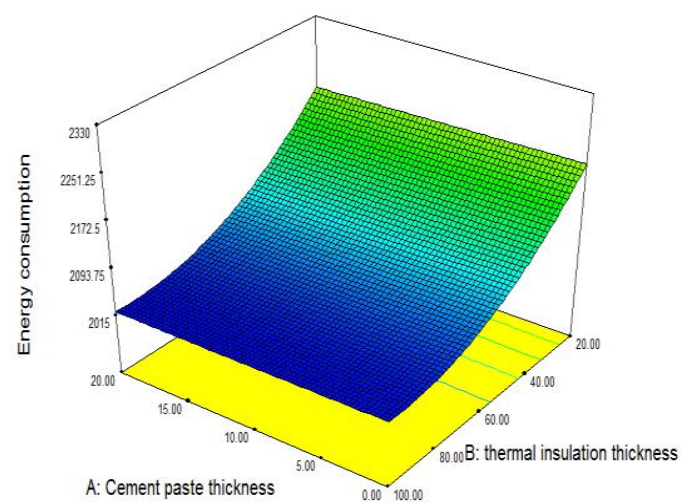

(c) East

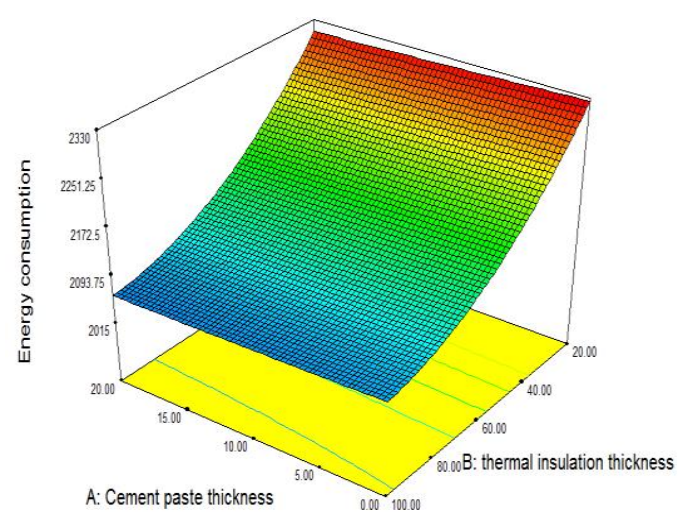

(d) South

Energy consumption

2324

2018.9 
Figure 8- Brick wall building: Interaction of cement plaster thickness and thermal insulation thickness with annual cooling energy consumption $(\mathrm{KWh})$ for different orientations.

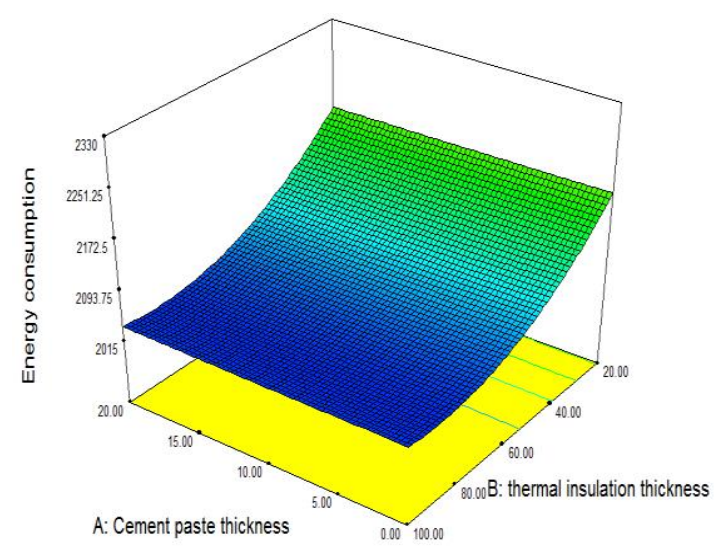

(a) North

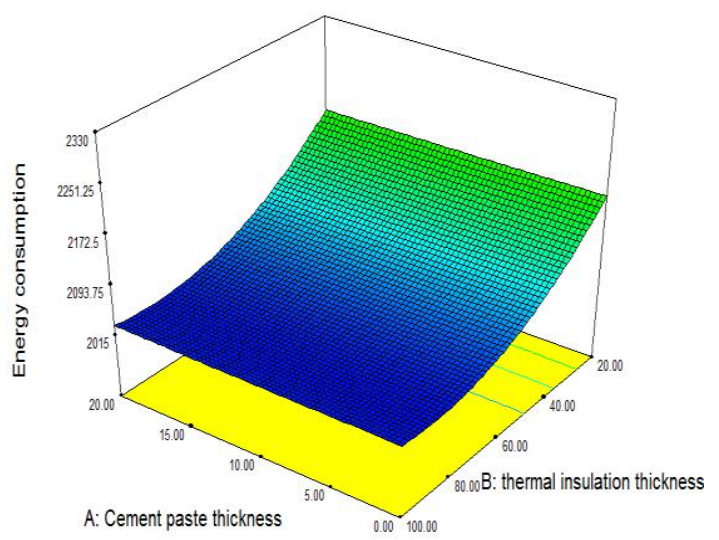

(b) West)

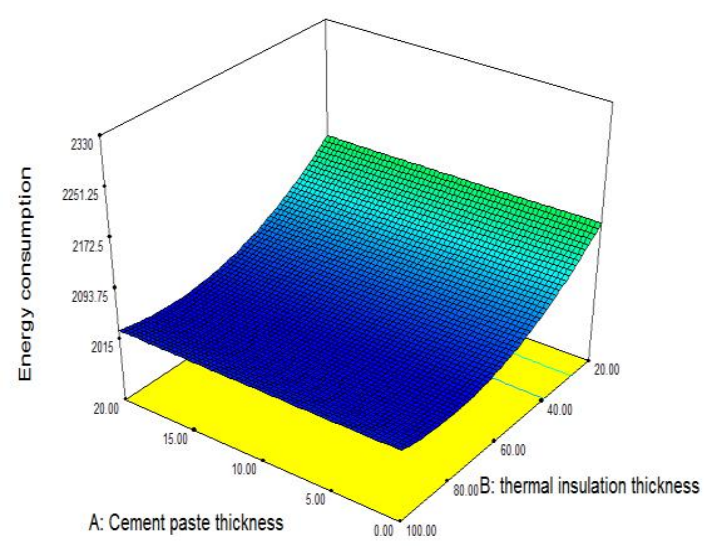

(c) East

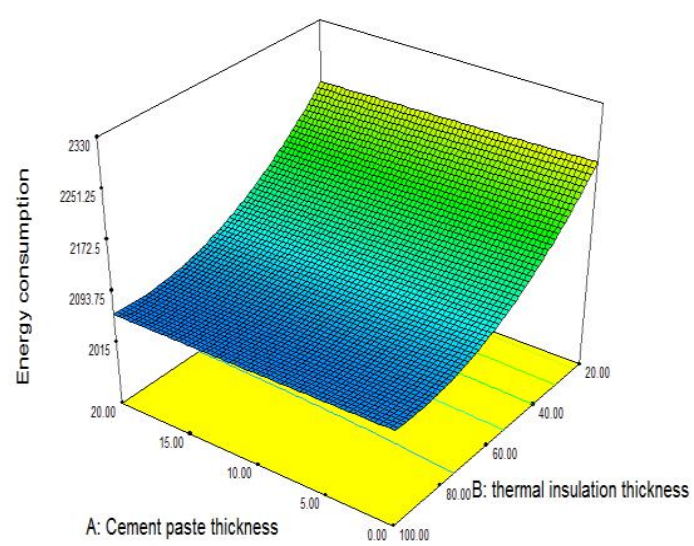

(d) South

\subsection{Optimization}

Although thick insulation reduces annual energy consumption, material costs and indoor space are two controversial issues. In order to achieve minimum annual energy consumption, a precise design optimization study was carried out by utilizing RSM, which consists of mathematical and statistical optimization methods. The optimized design is based on minimum usage of thermal insulation between 20 and $100 \mathrm{~mm}$ and minimum energy consumption, while the cement plaster thickness ranges from 0 to $20 \mathrm{~mm}$ for various orientations. The results indicate that minimum energy consumption is achievable for the east-oriented bungalow constructed with brick wall containing $31.51 \mathrm{~mm}$ EPS and $16.39 \mathrm{~mm}$ cement plaster in the wall interior (Fig. 9). To determine the optimum insulation thickness for the available buildings, the 
optimization process was repeated for each orientation and type of wall. The optimized design is based on minimum usage of thermal insulation between 20 and $100 \mathrm{~mm}$ and minimum energy consumption, while the cement plaster thickness ranges from 0 to $20 \mathrm{~mm}$ for the selected orientations and walls (Table 7). Fig. 10 and Fig. 11 present the relations between optimum insulation thicknesses and indoor cement plaster thicknesses in the 0 to $20 \mathrm{~mm}$ range.

Figure 9 - Optimum design suggested based on optimization.

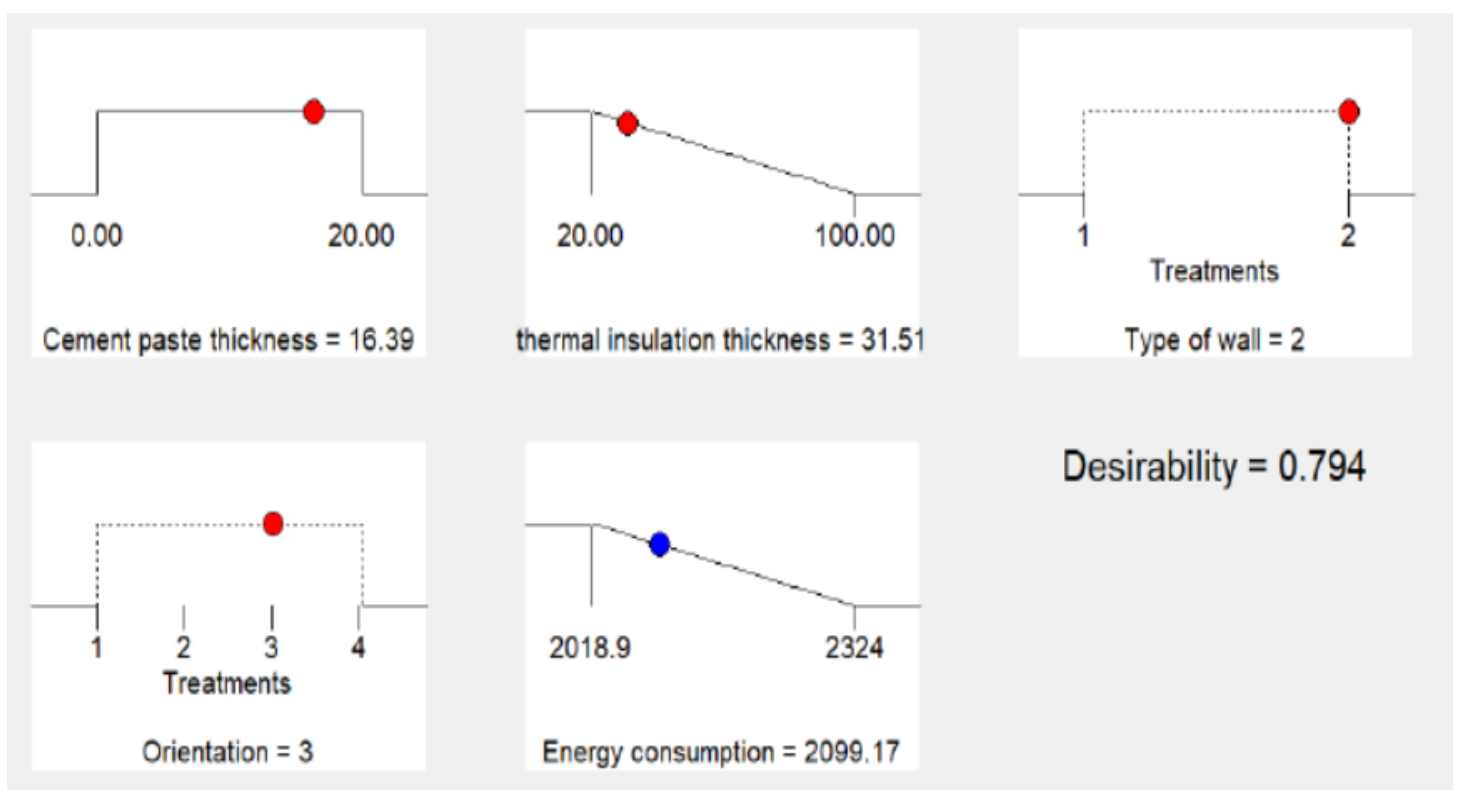

Table 7- Annual cooling energy consumption based on the optimum thermal insulation thicknesses for different walls and orientations.

\begin{tabular}{|c|c|c|c|c|}
\hline $\begin{array}{l}\text { Type of } \\
\text { wall }\end{array}$ & Orientation & $\begin{array}{l}\text { Optimum } \\
\text { thermal insulation } \\
\text { thickness } \\
(\mathrm{mm})\end{array}$ & $\begin{array}{l}\text { Thickness of inside cement } \\
\text { plaster } \\
(\mathrm{mm})\end{array}$ & $\begin{array}{c}\text { Annual cooling energy } \\
\text { consumption } \\
\text { (KWh) }\end{array}$ \\
\hline \multirow{4}{*}{ Concrete } & North & 47.8 & 20 & 2134.51 \\
\hline & West & 46.5 & 20 & 2127.28 \\
\hline & East & 41.6 & 20 & 2116.83 \\
\hline & South & 53.1 & 20 & 2157.23 \\
\hline \multirow{4}{*}{ Brick } & North & 38.4 & 15.6 & 2118.38 \\
\hline & West & 37.1 & 13.20 & 2111.56 \\
\hline & East & 31.5 & 16.39 & 2099.17 \\
\hline & South & 43.3 & 20 & 2139.22 \\
\hline
\end{tabular}


Figure 10- Concrete wall building: Relation between optimum insulation thickness ( $\mathrm{mm}$ ) and cement plaster thickness (mm).

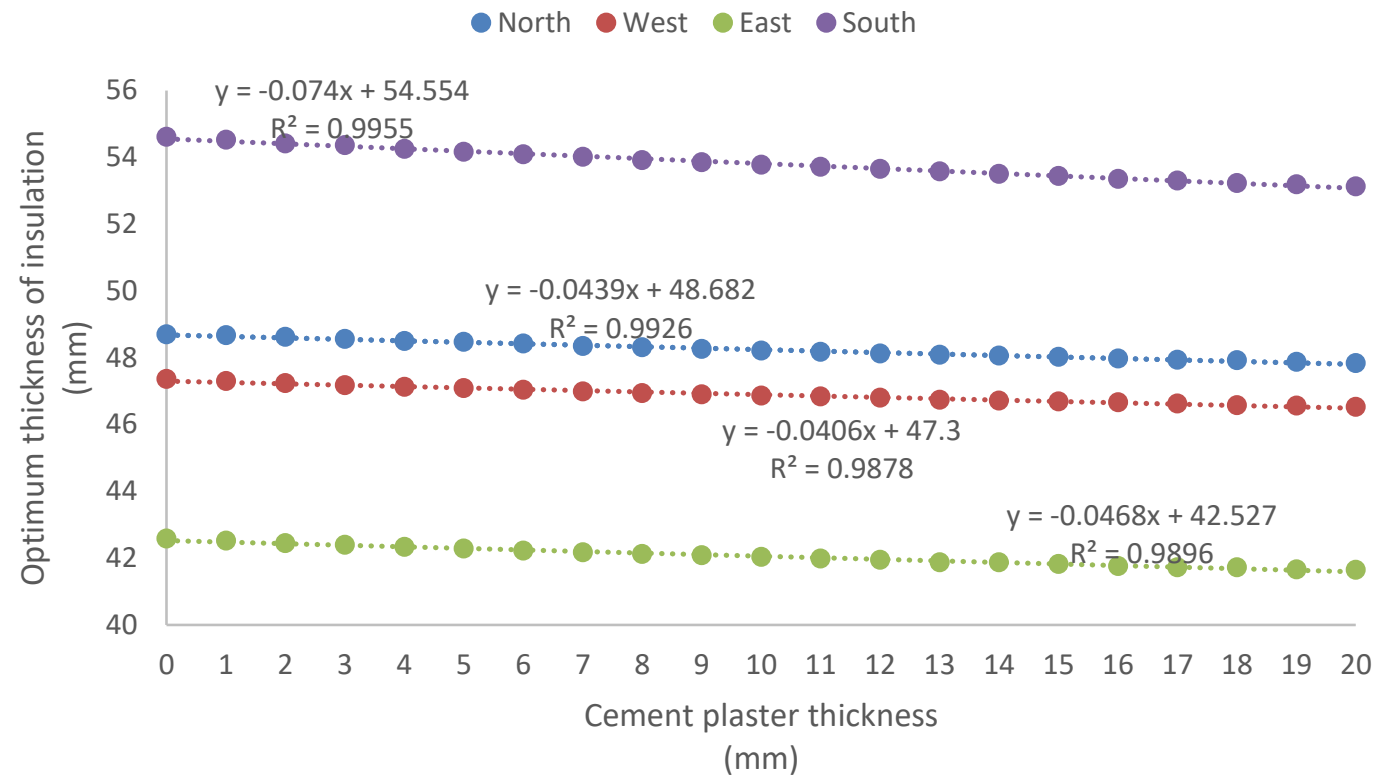

Figure 11 - Brick wall building: Relation between optimum insulation thickness (mm) and cement plaster thickness $(\mathrm{mm})$.

North West East South

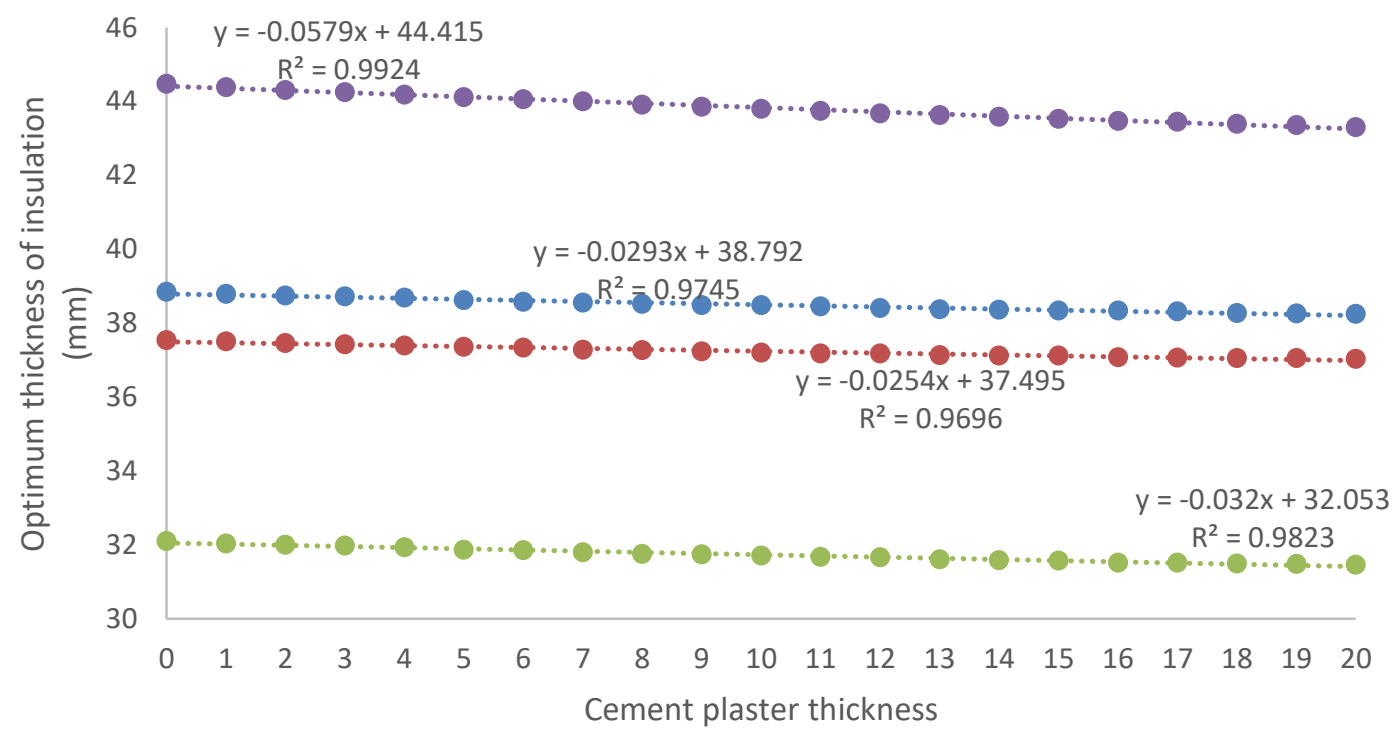

(mm)

Finally, the amount of annual cooling energy reduction was achieved by comparing the energy consumption in buildings when excluding EPS and cement plaster, and including EPS and cement plaster in optimized amounts. According to Fig. 12 and Fig. 13, using optimum EPS insulation thicknesses can reduce energy consumption by about 9 to $12 \%$ and 6 to $9 \%$ with concrete and brick walls, respectively. 
Figure 12 - Annual cooling energy consumption of concrete buildings including and excluding EPS and plaster

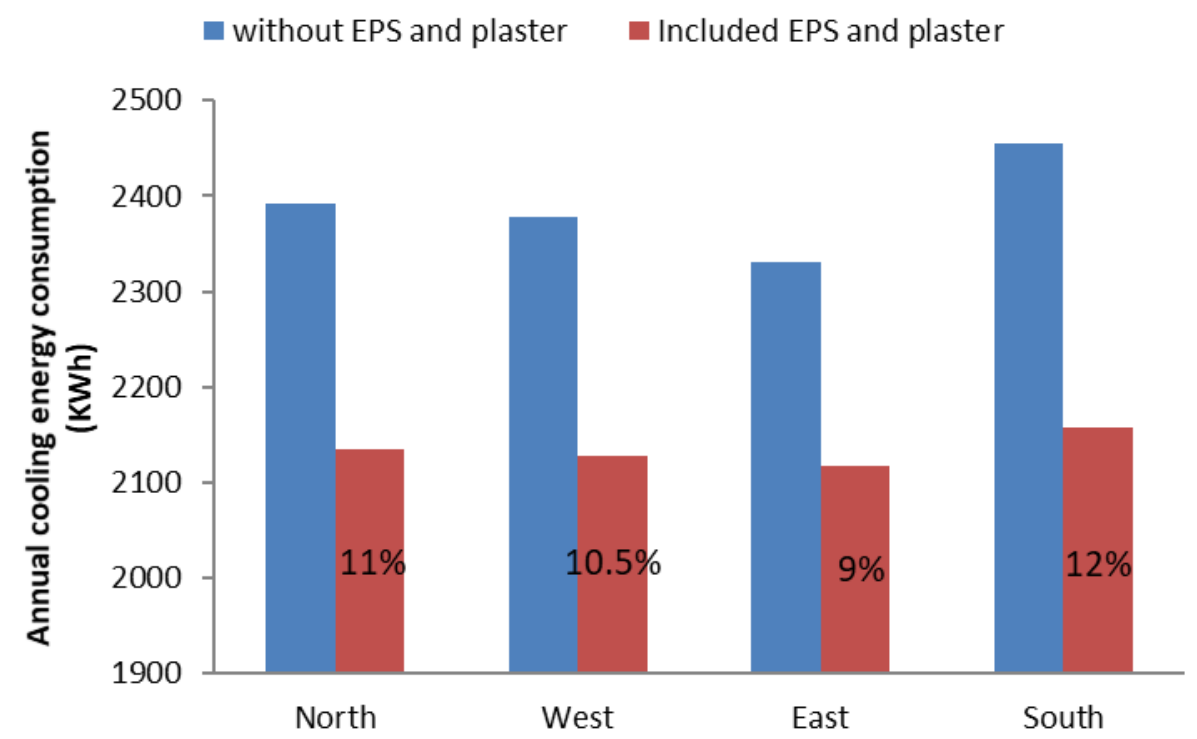

Figure 13 - Annual cooling energy consumption of brick buildings including and excluding EPS and plaster.

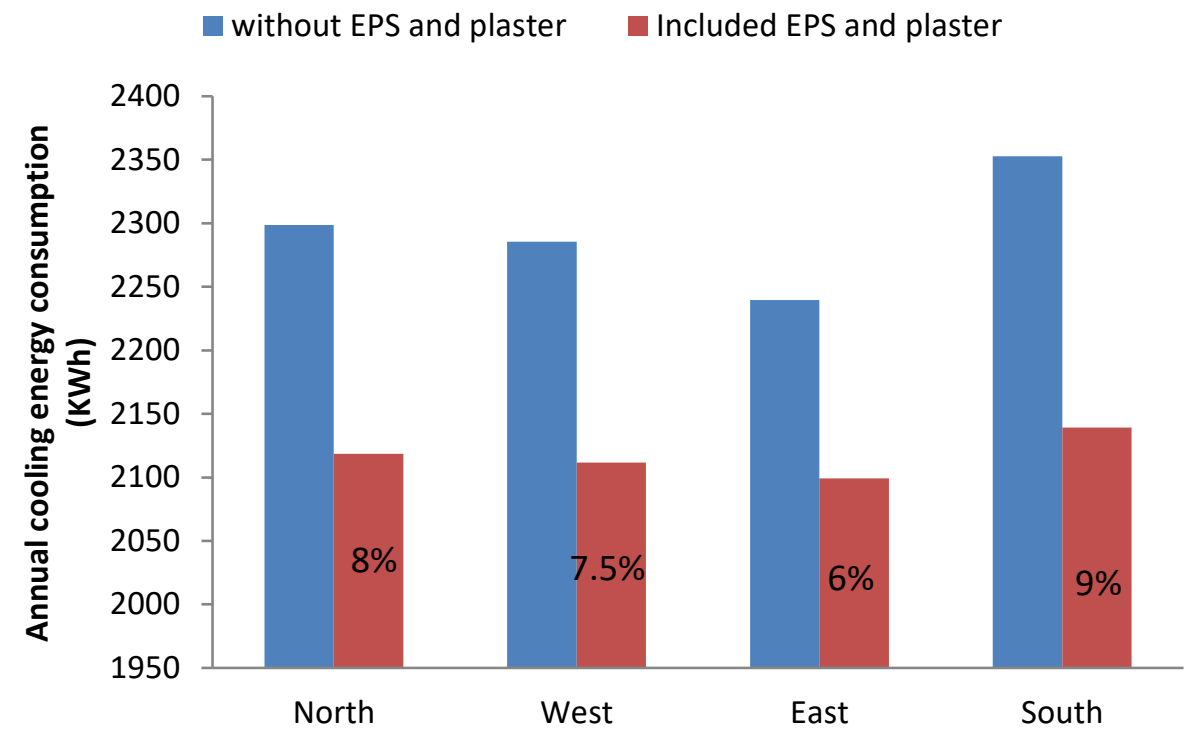

\section{CONCLUSIONS}

Residential buildings in Malaysia are responsible for about $19 \%$ of the total energy consumption. Heat transfer through the building envelope is considered one of the main reasons for energy expenditure in the building sector. Wall material type and topology, building orientation and material type, insulation thickness and wall finishing affect the heat transfer and energy consumption of buildings.
Adding thermal insulation to the interior surface of external walls and covering the interior and exterior sides of walls with some finishing such as cement plaster are useful strategies to reduce energy consumption of existing buildings. It is vital to consider the optimum thickness of thermal insulation to reduce material costs keeping in view environmental impacts and internal spaces. 
This study was carried out to examine the effects of thermal insulation and cement plaster thickness on the annual cooling energy consumption of a bungalow building in Malaysia and to find the optimum thickness of EPS based on wall type, building orientation and cement plaster thickness. eQUEST software was used to simulate the annual cooling energy consumption of a bungalow building based on different $U$ values of two types of walls of different sizes and orientations. Design-Expert software was used to design, analyze and optimize the statistical results.

The quadratic equations and 3D surface graphs indicate that the influence of EPS thickness is more significant than cement plaster thickness on annual cooling energy consumption. The optimum EPS thickness decreases with the increment in cement plaster thickness for different orientations and wall types. The optimum EPS thickness ranges from $31.5 \mathrm{~mm}$ to $53.1 \mathrm{~mm}$ based on wall type, orientation and cement plaster thickness. Therefore, utilizing the optimum EPS thickness and cement plaster on the interior side of external walls decreases the annual cooling energy consumption from 6 to $12 \%$ according to wall type and orientation.

\section{REFERENCES}

1 Ahmad, S. S., \& Szokolay, S. V. (2007). The performance of a partially air conditioned apartment building in Kuala Lumpur. Paper presented at the 24th International conference on Passive and Low Energy Architecture, PLEA 2007.

2 Al-Sanea, S. A., Zedan, M., Al-Mujahid, A., \& Al-Suhaibani, Z. (2016). Optimum Rvalues of building walls under different climatic conditions in the Kingdom of Saudi Arabia. Applied Thermal Engineering, 96, 92-106.

3 Asadi, I., Hussein, I., \& Palanisamy, K. (2014a). Analysis on Thermal Comfort of AirConditioned Buildings in Malaysia: Case Study of Universiti Tenaga Nasional. Paper presented at the Applied Mechanics and Materials.

4 Asadi, I., Hussein, I., \& Palanisamy, K. (2014b). Indoor Environmental Quality (IEQ) Acceptance of Air Conditioned Buildings in Malaysia: Case Study of Universiti Tenaga Nasional. Paper presented at the Advanced Materials Research.
5 Asadi, I., Mahyuddin, N., \& Shafigh, P. (2017). A review on indoor environmental quality (IEQ) and energy consumption in building based on occupant behavior. Facilities, 35(11/12), 684-695.

6 Asadi, I., Shafigh, P., Hassan, Z. F. B. A., \& Mahyuddin, N. B. (2018). Thermal conductivity of concrete-A review. Journal of Building Engineering.

7 Ashouri, M., Astaraei, F. R., Ghasempour, R., Ahmadi, M. H., \& Feidt, M. (2016). Optimum insulation thickness determination of a building wall using exergetic life cycle assessment. Applied Thermal Engineering, 106, 307-315.

8 Axaopoulos, I., Axaopoulos, P., Panayiotou, G., Kalogirou, S., \& Gelegenis, J. (2015). Optimal economic thickness of various insulation materials for different orientations of external walls considering the wind characteristics. Energy, 90, 939-952.

9 Bhattacharjee, B., \& Krishnamoorthy, S. (2004). Permeable porosity and thermal conductivity of construction materials. Journal of Materials in civil Engineering, 16(4), 322-330.

10 Braulio-Gonzalo, M., \& Bovea, M. D. (2017). ENVIRONMENTAL AND COST PERFORMANCE OF BUILDING'S ENVELOPE INSULATION MATERIALS TO REDUCE ENERGY DEMAND: THICKNESS OPTIMISATION. Energy and Buildings.

11 Derradji, L., Imessad, K., Amara, M., \& Errebai, F. B. (2017). A study on residential energy requirement and the effect of the glazing on the optimum insulation thickness. Applied Thermal Engineering, 112, 975-985.

12 Dombayc1, Ö. A. (2007). The environmental impact of optimum insulation thickness for external walls of buildings. Building and Environment, 42(11), 3855-3859.

13 Emmel, M. G., Abadie, M. O., \& Mendes, N. (2007). New external convective heat transfer coefficient correlations for isolated low-rise buildings. Energy and Buildings, 39(3), 335-342.

14 Gheshlaghi, R., Scharer, J., Moo-Young, M., \& Douglas, P. (2008). Application of statistical design for the optimization of 
amino acid separation by reverse-phase HPLC. Analytical biochemistry, 383(1), 93102.

15 Hassan, A. S., \& Al-Ashwal, N. T. (2015). Impact of Building Envelope Modification on Energy Performance of High-Rise Apartments in Kuala Lumpur, Malaysia.

16 Incropera, F., \& DeWitt, D. (1985). Introduction to heat transfer.

17 Iqbal, I., \& Al-Homoud, M. S. (2007). Parametric analysis of alternative energy conservation measures in an office building in hot and humid climate. Building and Environment, 42(5), 2166-2177.

18 Jamaludin, N., Mohammed, N. I., Khamidi, M. F., \& Wahab, S. N. A. (2015). Thermal comfort of residential building in Malaysia at different micro-climates. Procedia-Social and Behavioral Sciences, 170, 613-623.

19 Ji, R., Zhang, Z., He, Y., Liu, J., \& Qu, S. (2017). Simulating the effects of anchors on the thermal performance of building insulation systems. Energy and Buildings, 140, 501-507.

20 Mahlia, T., \& Iqbal, A. (2010). Cost benefits analysis and emission reductions of optimum thickness and air gaps for selected insulation materials for building walls in Maldives. Energy, 35(5), 2242-2250.

21 Mahlia, T., Taufiq, B., \& Masjuki, H. (2007). Correlation between thermal conductivity and the thickness of selected insulation materials for building wall. Energy and Buildings, 39(2), 182-187.

22 Martínez-Molina, A., Tort-Ausina, I., Cho, S., \& Vivancos, J.-L. (2016). Energy efficiency and thermal comfort in historic buildings: A review. Renewable and Sustainable Energy Reviews, 61, 70-85.

23 Mirrahimi, S., Mohamed, M. F., Haw, L. C., Ibrahim, N. L. N., Yusoff, W. F. M., \& Aflaki, A. (2016). The effect of building envelope on the thermal comfort and energy saving for high-rise buildings in hot-humid climate. Renewable and Sustainable Energy Reviews, 53, 1508-1519.

24 Muhammad-Sukki, F., Ramirez-Iniguez, R., Abu-Bakar, S. H., McMeekin, S. G., \& Stewart, B. G. (2011). An evaluation of the installation of solar photovoltaic in residential houses in Malaysia: Past, present, and future. Energy Policy, 39(12), 79757987.

25 Naji, S., Çelik, O. C., Alengaram, U. J., Jumaat, M. Z., \& Shamshirband, S. (2014). Structure, energy and cost efficiency evaluation of three different lightweight construction systems used in low-rise residential buildings. Energy and Buildings, 84, 727-739.

26 Ozel, M. (2011). Thermal performance and optimum insulation thickness of building walls with different structure materials. Applied Thermal Engineering, 31(17), 38543863.

27 Parameshwaran, R., Kalaiselvam, S., Harikrishnan, S., \& Elayaperumal, A. (2012). Sustainable thermal energy storage technologies for buildings: a review. Renewable and Sustainable Energy Reviews, 16(5), 2394-2433.

28 Rahman, A., Malik, A., \& Ismail, M. (2008). Future Design In An Energy Efficient Building As An Identity Of A Malaysian Tropical Architecture With Emphasis On Photovoltaic Technology And Passive Solar Building Design Elements.

29 Roberz, F., Loonen, R., Hoes, P., \& Hensen, J. (2017). Ultra-lightweight concrete: Energy and comfort performance evaluation in relation to buildings with low and high thermal mass. Energy and Buildings, 138, 432-442.

30 Sabouri, S., \& Zain, M. F. M. (2011). Cooling energy and passive energy saving strategies for master bedroom of a tropical bungalow house. J. Surv. Constr. Prop, 2(1).

31 Saidur, R., Sattar, M., Masjuki, H., Abdessalam, H., \& Shahruan, B. (2007). Energy and exergy analysis at the utility and commercial sectors of Malaysia. Energy Policy, 35(3), 1956-1966.

32 Schiavoni, S., Bianchi, F., \& Asdrubali, F. (2016). Insulation materials for the building sector: A review and comparative analysis. Renewable and Sustainable Energy Reviews, 62, 988-1011.

33 Shafigh, P., Asadi, I., \& Mahyuddin, N. B. (2018). Concrete as a thermal mass material 
for building applications-A review. Journal of Building Engineering.

34 Simona, P. L., Spiru, P., \& Ion, I. V. (2017). Increasing the energy efficiency of buildings by thermal insulation. Energy Procedia, 128, 393-399.

35 Tabatabaeikia, S., Ghazali, N. N. B. N., Chong, W. T., Shahizare, B., Izadyar, N., Esmaeilzadeh, A., \& Fazlizan, A. (2016). Computational and experimental optimization of the exhaust air energy recovery wind turbine generator. Energy Conversion and Management, 126, 862-874.

36 Ucar, A., \& Balo, F. (2009). Effect of fuel type on the optimum thickness of selected insulation materials for the four different climatic regions of Turkey. Applied Energy, 86(5), 730-736.
37 Yau, Y., Chew, B., \& Saifullah, A. (2013). A field study on thermal comfort of occupants and acceptable neutral temperature at the National Museum in Malaysia. Indoor and Built Environment, 22(2), 433-444.

38 Yu, J., Yang, C., Tian, L., \& Liao, D. (2009). A study on optimum insulation thicknesses of external walls in hot summer and cold winter zone of China. Applied Energy, 86(11), 25202529.

39 Zhang, D., Li, Z., Zhou, J., \& Wu, K. (2004). Development of thermal energy storage concrete. Cement and Concrete Research, 34(6), 927-934.

40 Zhang, W., Min, H., Gu, X., Xi, Y., \& Xing, Y. (2015). Mesoscale model for thermal conductivity of concrete. Construction and Building Materials, 98, 8-16. 